\title{
CONSTRUCTION OF IMAGINED GEOGRAPHIES THROUGH LAW: THE CASE OF JUDAIZATION OF THE NEGEV DESERT
}

\begin{abstract}
This article draws on the postcolonial legal theories and the concept of imaginative geographies, aiming to shed light on the process of producing and realizing Israeli representations of the Negev Desert through the implementation of legal regulations. The focus is on chosen imaginations of the Negev Desert, researched here as a case study of material realisation of imaginative geographies. In the analysis, symbolic narratives, visions of spaces, and new categories, intertwined in legal acts as their foundations, justifications and goals are underlined. The conclusions of presented study show that imaginations and visions can be in fact reproduced in space through legal regulations, and in the analysed case law has three aspects: it is an expression of imagined geographies; it translates those visions into technical terms; and lastly, the implementation of its provisions becomes the main instrument of producing those representations in reality.
\end{abstract}

Keywords: imaginative geographies, space, Negev Desert, Israel, Judaization, postcolonialism, Bedouins.

\section{BUDOWA GEOGRAFII WYOBRAŻONYCH POPRZEZ PRAWO: PRZYPADEK JUDAIZACJI PUSTYNI NEGEW}

Streszczenie. Artykuł czerpie z postkolonialnych teorii prawnych i koncepcji geografii wyobrażonych, rzucając światło na proces tworzenia i realizacji izraelskich reprezentacji pustyni Negew poprzez wdrażanie regulacji prawnych. Nacisk położony jest na wybrane wyobrażenia pustyni Negew badane jako studium przypadku materialnej realizacji geografii wyobrażonych. W analizie podkreślane są symboliczne narracje, wizje przestrzeni i nowe kategorie, wplecione w akty prawne jako ich fundamenty, uzasadnienia i cele. Wnioski z przedstawionego studium pokazują, że wyobrażenia i wizje mogą być faktycznie odtwarzane w przestrzeni poprzez regulacje prawne, a w analizowanym przypadku prawo ma trzy aspekty: jest wyrazem geografii wyobrażonych; przekłada te wizje na terminy techniczne; i wreszcie implementacja jego przepisów staje się głównym narzędziem produkcji tych przedstawień w rzeczywistości.

Słowa kluczowe: geografie wyobrażone, przestrzeń, pustynia Negew, Izrael, judaizacja, postkolonializm, Beduini.

* Jagiellonian University in Krakow, Poland, Faculty of Law and Administration, Department of Sociology of Law, ewa.gorska@alumni.uj.edu.pl 
Colonial law is closely associated with specific ideas of space. Historically, images of wild feral land, unpopulated or inhabited by native people portrayed as primitive, were used by European colonialists as an argument for taking over, populating and transforming occupied areas in the name of civilizing missions (Comaroff 2001, 309). According to the rhetoric used by Zionist lobbyists and politicians before Israel was created, Palestine's territories were represented as such empty area, waiting for Jewish settlers (George 1979). Especially in the Negev (ar. Naqab) a desert region, now constituting as much as $60 \%$ of present-day Israel, this Orientalist idea was fuelled by seemingly barren natural landscapes. However, the reality of those terrains were different - for centuries they were inhabited by Palestinian Bedouins, semi-nomadic shepherds of Arab ethnicity, who cultivated the lands and used it for pasture (Oren 1989; Rosen-Zvi 2004, 43). It was therefore not vacant, not neglected, and not waiting for new settlers. After the creation of the new State, Israel undertook actions to reshape its spatiality in line with its imaginations. To achieve that goal, it employed law in its service, implementing a complex strategy to recreate the space.

This article draws on the postcolonial legal theories, and the concept of imaginative geographies, developed by Edward Said in his discussion on Orientalism (1978). The analysis presented here aims to shed light on the process of producing and realizing Israeli representations of the Negev through the implementation of regulations. It underlines the symbolic narratives, visions of spaces, and new categories, intertwined in legal acts as their foundations, justifications and goals. The focus is on chosen imaginations of the Negev Desert, used here as a case study of state practices of using the law in the name of imaginative geographies.

\section{IDEAS OF SPACE AND ISRAELI FOCUS ON LEGALITY OF LAND SEIZURE}

Imaginative geographies are collective imaginations, representations of places and people, often unconscious and ambiguous (Said 1978; Gregory 1995; 2004). They are constructions that "fold distance into difference through a series of spatializations" (Gregory 2004), creating partitions and binary oppositions in how space is perceived, constructing a wide gap between what is familiar and unfamiliar, demarcating "ours" and "theirs." Though they are produced in specific spatial contexts, they are also performative, and affect the material landscapes. If space is socially constructed and constantly reproduced (Lefebvre 1991, 31-33), imaginative geographies are some of the projections affecting spatial changes. As they are rooted in biased representations of the "Other," they are often employed to devise, justify and legitimize colonialism and occupation (Gregory 1995; 2004). 
Such is the case of Israel, created in 1948 and considered an ethnocratic settler state. Ethnocratic regimes are "states that maintain a relatively open government, yet facilitate a non-democratic seizure of the country and polity by one ethnic group" (Yiftachel 1999, 364). Settler states are based on colonial or ethnocratic ideologies, segregation, exclusion of the indigenous people, and the goal of achieving territorial and political dominance by the settling community (Kedar 2003). The power exercised by that community reaches different spheres to ascertain its control. In case of Israel, the ruling ethno-religious majority is pursuing a settler strategy of Judaization, to establish geographical, demographic, political and cultural dominance of the Jewish people in the country and the territories occupied by it. Spatially, as Oren Yiftachel $(2004 ; 2006)$ argues, ethnocratic states are characterized by a specific structure, making marginalized groups of indigenous peoples function in "grey spaces" - outside society, on the periphery, out of control of the administration. These groups are often not included in hegemonic communities not because of a shortage of possibilities, but lack of willingness of official institutions, pursuing settler policies. The "grey spaces" become the semi-invisible zones, into which all that does not fit the prescribed and designed imaginative geography is pushed away.

One of the tools of spatial change and reshaping is law. Legal norms convey and express certain goals, aspirations and changes postulated by the legislator, as the law often does not define reality, but offers postulates about desired actions and conditions that should be achieved. Norms, their frameworks, phrasing, and enforcement can also affect the physical sphere and lead to the creation of new social facts. As David Delaney $(2014,239-240)$ writes: "the «legal» is not simply poured into preexisting «spaces» but, rather, is constitutive of spatialities, spatial relationships, spatial performances, and experiences, as these, in turn, condition the lived character of the legal." Regulations may therefore be used strategically to produce desired landscapes, making imaginative geographies a reality. The juristic language in such cases is not neutral; law uses codes and categorizations to rename objects, scenes, and conditions to fit political discourses and aims. Those codes constructed in language, supported by official power, can reshape reality and constitute what has been imagined. As Shamir (1996) mentions, generating new categories and terms is also part of the strategy for building different spatial hierarchies and giving different meanings to colonized spaces.

The Negev Desert and its indigenous community can be a revealing case study of all above-mentioned strategies and mechanisms. Two parallel processes took place during the creation of the state of Israel: on one hand, the formation of externally democratic political and juridical institutions, and on the other, the processes of the takeover of the territory by an ethnically dominant group using repression and coercion (Yiftachel 1999). What's more, the second of these processes was often hidden behind legal procedures and institutions, whose structure and content were created precisely to conceal the activities being 
conducted behind a façade of neutrality (Kedar 2003; Rangwala 2004; Cook 2013). The use of law in such a way is one of the relatively permanent ways used by colonial and settler states to expropriate colonized areas from native inhabitants, normalize the spatial results of armed and internal conflicts, and to legitimize the power of the dominant group and colonial rule (Comaroff 2001, 309; Bisharat 1993; Forman and Kedar 2003).

Israel pressed very hard to create legalistic foundations for the occupation and seizure of land, although during the 1948 war the property of Palestinian refugees, and even those who did not flee, could theoretically be simply taken over by the state and Jewish settlers and become theirs as a fait accompli. Yet, such a takeover would not be in line with the idea of the rule of law being established and the narrative of creating "the only democracy in the Middle East," would allow greater support for the claims of expropriated Palestinians and refugees, and could raise doubts and opposition by Israeli citizens. Relying on juristic arguments in internal political rhetoric legitimizes all actions of the state while describing them in technical and neutral terms (Kedar 2003). Consequently, in the eyes of Jewish citizens, the idea of Israel as a democratic state might be upheld or even strengthened. Also on the international stage, the unemotional language of acting by the law created a picture of Israel as a state of justice, which was more likely to be assessed as fair by the international community. Moreover, that approach and enforcement of new regulations, rooted in a Western legal traditions and spirit, in the Middle East, could also be considered as a certain "civilizational mission" of democratization of the "savage" places (Marx and Meier 2005; RosenZvi 2004, 48). In fact, it will be argued here that an Orientalistic narrative of a "civilisational" mission has been used by the Israeli government constantly in juristic discourses. Underneath such justifications and narrations, introduced laws concerning space have been part of a long-term political strategy, leading to the production of imagined geographies.

\section{2. (RE)CONSTRUCTING THE VISION OF "THE LAND WITHOUT PEOPLE"}

The main imaginative representation of the Negev, already mentioned, was the prolific idea of "land without a People for a People without a land." Due to armed conflict in 1948 and following years this concept had almost become a reality in the Negev. During the war, known as "Independence War" by the Israelis and as Nakba (ar. "catastrophe") by the Palestinians, Israeli forces physically took over $78 \%$ of the entire mandate territory of Palestine ${ }^{1}$ (Cook 2013, 2). Around 80-85\% of Palestinians (at least 700-800,000) fled or were forcibly displaced from lands,

\footnotetext{
${ }^{1}$ The rest was seized in 1967.
} 
which are now part of the Jewish State ${ }^{2}$ (Pappé 2006, xiii). As for the Negev, about $70-85,000$ of the Bedouins were forced to leave their lands. Many were uprooted by the Egyptian army, some were pushed out after the Israeli forces took over the desert, others fled for fear of their lives during the fighting. After the end of hostilities, around 1953, only about 11-12,000 Bedouins (19 from 95 tribes) remained in the region (Rosen-Zvi 2004, 45; Nasasra 2012, 92-93; Amara and Yiftachel 2014). To maintain the achieved spatial and demographic advantage, the new government closed the borders and blocked all attempts of refugees to return (Boteach 2008; Swirski and Hasson 2006, 9).

Nevertheless, the lands of the Negev were not "empty" yet, as some indigenous inhabitants stayed in their homeland. Israel started a resettling process, to achieve the desired spatial and demographic changes in the south of Israel. To depopulate the region, the army demarcated an enclosed area - Siyag (ar. fence) - near Beer Sheva. It covered about $1000 \mathrm{~km}^{2}$, or $8 \%$ of the desert, and was characterized by unfavourable conditions for agriculture and pasture. Since the early 1950s, most of the Bedouins were forcibly resettled there, and only a few managed to avoid this fate (Rangwala 2004; Amara and Yiftachel 2014). Legally, the concentration of Bedouins in the zone was based on Israeli military orders, and the resettled communities became subject to military law (Boteach 2008). The Armed forces executing the action managed communication about it in a way to minimize resistance - informing the indigenous communities that it was temporary (Rosen Zvi 2004, 45; Nasasra 2012, 92-93). That impression of the temporariness of the resettlement was further maintained by an almost complete lack of any permanent housing structures in the area, as the Israeli government refused to grant building permits, forcing newcomers to live in tents and barracks. In spite of that, the displacement was not short-timed and the Bedouins were required to stay in the enclosed area until 1966, in some cases more than a decade (Boteach 2008; Amara and Yiftachel 2014). The authorities declared the rest of the desert a military zone and banned Bedouins from entering it without a, rarely issued, permit (Rosen-Zvi 2004, 45; Swirski and Hasson 2006, 9). Depopulating the region fitted the vision of the vast, empty, undeveloped domain, waiting for the Jewish community.

\section{CREATING ISRAELI TERRITORY FROM “ABSENTEE" LANDS}

Even though the Bedouins of the Negev were concentrated in the Siyag, their land did not yet belong to the new state. At the end of the war, in Israel's new borders, only about $13.5 \%$ of the territory was owned by Jews or was under the formal control of the new state (Forman and Kedar 2004). The ownership rights of

${ }^{2}$ At the same time, already existing Jewish population doubled in five years between 1946 and 1951, reaching the number of 1.4 million (Forman and Kedar 2004; Kimmerling 1983). 
Bedouins, recognized previously by the Ottoman and British Authorities (Nasasra 2012, 95) couldn't be ignored by the legalistically-oriented Jewish state, and the expropriation had to be made lawful.

Since 1950, the Israeli government started creating and enforcing new regulations legitimizing land takeover, also introducing in them new categories of subjects and spaces. A first major legal act regarding land and real estate was Absentee's Property Law 5710-1950. According to its provisions, plots owned by the refugees, who fled abroad (and could not come back due to closed borders), were defined as "abandoned," 3 and their owners as "absentees." A newly appointed Custodian for Absentees' Property was entrusted with their possessions. The Custodian was forbidden from transferring the ownership rights of "absentees" to any person or institution other than the governmental Development Agency. Any actions countering the act or its institutions were punishable (Absentee's Property Law, 5710-1950). A committee composed of Israeli Army officers considered eventual appeals against land confiscation, generally to the detriment of the former owners (Shehadeh 1993, 63; Cook 2013, 74-75). It is currently estimated that around $70-88 \%$ of Israel's territory was declared as "abandoned" by Palestinians, and consequently taken over by the state (Rangwala 2004). Authorities designed another juristic category to define internal refugees, so they could fall under the above-mentioned act as well. New documents defined the Palestinians who were still present in Israel, but absent from their estate (after fleeing the war or being forcibly displaced by Jews), as "present absentees." About 30-35,000 people $-25 \%$ of Palestinians who remained in Israel - were classified as such $^{4}$ (Benvenisti 2000, 201; Cook 2013, 98). In 1952, under the new Citizenship Act, they obtained Israeli citizenship, but their land and estate ownership rights were transferred to the Custodian (Cook 2013, 34-35; Rangwala 2004).

The Absentee's Property Law 5710-1950 constructed new legal categories of "absentee" and "present absentee." While the language of this act did not conceal the reality that the Negev has not been in fact "empty land" before 1948, it used carefully chosen terms to present its recent history neutrally. It cultivated an illusion that the territory have been, for some reason, "abandoned" by the previous owners, who were now just "absent," but their possessions were dutifully entrusted to office of the Custodian. Such terms conveyed a picture of calm emigration of residents, abandoning worthless lands and possessions, rather than the image of expulsions, forced resettlement and expropriation. The previous owners become anonymous and non-existent "absentees," rather than refugees, sometimes living just a few kilometres away from their previous homes.

${ }^{3}$ This act was interpreted so that it was not applied to Jews living in mandatory Palestine, who might have left their lands during the war or, resettled before or after (Dajani 2005, 41).

${ }^{4}$ According to current estimates, about 250,000 "present absent" and their descendants live in Israel (Dajani 2005, 41). 
Real estate and the land of the "absentees" - whether refugees abroad or internally displaced persons - were not incorporated into state property until 1953. The Land Acquisition (Validation of Acts and Compensation) Law (5713-1953) settled the issue, stipulating that all areas not in the possession of the legal owner as of April 1, 1952, should be registered as state lands. The introduction of these provisions allowed for the complete transfer of ownership of the plots and properties of the refugees. In any case, the Custodian, although until 1953 merely a trustee of the seized grounds and real estate, by that time has already transferred much of the occupied areas to Jewish communities or sold them to the Jewish National Fund (JFN $\left.{ }^{5}\right)$ (Cook 2013, 34-35; Rangwala 2004). In result, in 1948-1953, around 350 new Israeli settlements (out of 370 built at that time) had already been established in the lands of the "absentees." For that reasons, the Land Acquisition Act was also applied retroactively, legitimizing expropriation for military purposes and the construction of Jewish settlements before 1953 (Dajani 2005, 41).

At the time when "abandoned" lands were declared state property, most of the Bedouins in the Negev Desert were forcibly resettled to Siyag so they could not counteract the process. Some who managed to stay in their homes (especially those native to the lands where Siyag was placed) tried to register their estate with the new authorities. However, not only were their customary ownership rights not recognized, but the Israeli courts also denied the validity of purchase contracts, property deeds and other documents issued prior to 1948. Those who insisted on staying either had to lease their plots from the government, which was interpreted as an official admission that the land belonged to the state, or were accused of trespassing (Rangwala 2004). In the eyes of the law, by that time the Negev was an empty land with no owners, and members of the indigenous community became "absentees" and "trespassers" within the region.

\section{MAKING THE JEWISH LAND BLOOM}

In the following years a handful of new laws affecting the space of the new country and the Negev were introduced. In 1953, government introduced the Act on the Jewish National Fund, granting the organization status of "landowner for the state." The properties belonging to the JNF are a trust of Jews from all over the world. The covenant between the State of Israel and the World Zionist Organization signed in 1961 confirms that the plots belonging to the JNF are in the hands of the state, but obliges the government to consult

${ }^{5}$ The Jewish National Fund (JNF, Keren Kajemet LeIsrael) is an international Zionist organization established in 1901 to amass the lands in Palestine for Jewish settlers (Jewish National Fund 2017). 
the JNF with all decisions (KKL-JNF - Israeli Government Covenant, 2017). In 1960, another two acts came into force - Basic Law: Israel Lands and the Israel Lands Law (5720-1960). The Basic Law consists of 3 articles, and above all prohibits any transfer of ownership of public property owned by the state, the Development Agency and the Jewish National Fund. The Israel Lands Administration Law, in turn, lists exceptions to the Basic Law, especially concerning areas belonging to the JNF. That act also established the Israeli Land Authority (ILA) - a government agency set up to administer territory owned directly by the state or managed by it under additional agreements (i.e. with the JNF). As Jonathan Cook shows $(2013,38,40)$, the purpose of handing over the management board to the JNF was to exclude Palestinians from potentially accessing land. As per the Statute of the Fund (Jewish National Fund n.d.), it may lease parcels only to Jews: in this way, it is not the state institution per se that implements practices discriminating against minorities living in the state, but a foundation ${ }^{6}$ that manages this institution.

The JNF has been also tasked with the mission to "make the desert bloom." In a 1951 speech, David Ben Gurion described a new vision of Israeli lands, revived and turned green by trees planted by Jewish hands (Fields 2017, 264). That representation of space was founded again on the myth of uninhabited desert, this time presented as infertile due to the inaction and carelessness of Bedouins (George 1979); for that reason, much of the process was focused on reshaping the Negev Desert (Fields 2017, 264-266). Since 2006, based on a long-term lease offered by the State, the JNF has been directly charged with afforestation of 30,000 hectares of the Negev (Tal 2006). The authorities chose European pine for afforestation - an evergreen and quickly growing tree, it allows a quick transformation of landscapes (Cook 2013, 40). Afforestation of terrain, in its political dimension, confirms its seizure and control over it. It also shapes collective memory, securing the Israeli hegemonic narrative against all facts in space that could violate it. For that reason Israel also planted the trees strategically, to hide ruins of former Palestinian villages, destroyed during the creation of Israel, thus indirectly counteracting their possible claims (Cook 2013, 136). On the imaginative level, planting of pine allowed for naturalization of areas and making the landscape more European, reminding the founders of Israel of their former homelands (Braverman 2009, 7-9). The JNF thus became the main institution constructing and producing imaginative geographies in Israel, reshaping the space in accordance with dreams of fertile Jewish land, familiar to the settlers of European descent.

${ }^{6}$ Moreover, the JNF is registered as a charitable foundation in the United States and Europe, which facilitates raising funds for further operations. 


\section{5. "CIVILISATIONAL MISSION" AND DISAPPEARING MINORITY}

When the Bedouins were permitted to leave the "restricted area" in the mid-1960s, most of their territories were already seized and legally owned by the State, and they had no place to cultivate or herd animals. The government offered to resettle them in specially designed and built cities (called "planned townships"), located in the enclosed zone of Siyag (Boteach 2008; Rosen-Zvi $2004,44,49)$. The actions were again supported by a narrative of the indigenous people as outsiders, who stand in opposition to "progress" and "modernity" represented by Israel (Amara and Miller 2012). Their resettlement in modern cities with access to plumbing, electricity and running water was therefore supposed to be an improvement from their "primitive" life. It was also aligned with Israeli visions of an urbanized and highly developed country. However, the townships for Bedouins did not, and do not, provide the same infrastructure conditions as already existing and developed Jewish cities in the region - in most of them, the level of services such as public transport, medical care and cultural institutions is deplorable (Abu-Sa'ad 2004). Restricting access to land and freedom of movement was a serious blow to the nomadic Bedouin identity, and, combined with lack of work opportunities in the "planned" townships, resulted in the conversion of Bedouins into a cheap labour force for developing Israeli settlements (Rangwala 2004). The political goal was to prevent this community from going back to their pastoral-agricultural lifestyle, and thereby negatively impacting its culture, identity and independent development. The long-term effect was the introduction of racial segregation in the Negev, the factual Judaization of most of the desert, and the sedentarization and concentration of Bedouins. This, in turn, also lead to the development of a specific culture of such cities, where the exclusion of disadvantaged communities is deepened by hegemonic, official narratives presenting "grey spaces" as dangerous areas, overwhelmed by crime, plunged into chaos and dirt (Yiftachel 2004; 2009). These narratives emphasize the sense of danger and defilement of "normal" residents of recognized parts of the city but never mention that their situation is a direct result of the lack of recognition by the government administration and refusal to guarantee access to infrastructure and services.

\section{MAKING THE OTHER INVISIBLE: ADMINISTRATIVE UNRECOGNITION AND GREY AREAS}

The resettlement to "planned townships" was met with opposition, and, in the last forty years, only half of the Bedouins from the Negev Desert moved there. Another half currently resides in so-called "unrecognised villages" (Rosen-Zvi 
2004, 44-46; Yiftachel 2009; Nasasra 2012, 98; Amara and Yiftachel 2014). Administrative recognition of certain settlements proves the existence of a housing estate as a legal fact and, consequently, also means that the state must fulfil its obligations regarding care and services for the residents. The "unrecognized villages" are deprived of those possibilities, even though $70-75 \%$ of them predate 1948 and are in areas inhabited by their clans for generations (whose inhabitants avoided resettlement); the remainder are settlements established in the Siyag by the internally displaced Bedouins (Fields 2017, 275).

Existence of such localities became a fact on basis of two laws. First, the Planning and Building Act (5725-1965) divided Israel's lands into residential, agricultural and industrial zones. As the existence of many Bedouin towns and settlements was ignored and they were not marked on maps or in documents (Boetach 2006), the areas of those villages were classified as agricultural, all construction on them was banned, and every built structure was to be demolished. Soon after in 1969, the Israeli authorities utilised Ottoman norms previously used to register ownership in the region. Prescription Law, 5718 1958, the Land (Settlement of Title) Ordinance (New Version), 5729-1969 (amended version of 5720-1960 law), and the Land Law, 5729-1969 evoked the classification incorporated in the Ottoman Land Code of 1858, especially the provisions concerning the wastelands - mawat. Mawat were defined as uninhabited grounds, not owned privately, lying outside of towns (Eisenman 1978, 76-78; Shmueili and Khamaisi 2015, 31). Under Ottoman law their legal ownership, nonetheless, could be obtained by constant cultivation ${ }^{7}$ (Rosen-Zvi 2004, 47; Cook 2013, 80). According to Israeli provisions, all plots classified as mawat became state property, ${ }^{8}$ and their inhabitation and cultivation had to be documented to be a basis for claims of ownership. In the case of the Bedouins, the Israeli courts did not recognize the temporary shelters of the nomads as residential buildings or shepherding as a form of cultivation (Rangwala 2004), preventing registration.

The situation of those localities has not changed much since 1969. Until now the Israeli administration refuses to recognize the localities in question on the basis of the aforementioned regulations regarding land ownership (claiming that they invaded the state territory illegally), spatial planning (illegal settlement and

${ }^{7}$ According to art. 103 of the Land Code of 1858, a person who "revived" part of the land through constant cultivation for at least 3 years, could claim ownership of it even without official permission. British authorities partly amended the Ottoman provisions and demanded the act of registration of the land. The Mewat Lands Regulation of 1921 abolished Art. 103 of the Ottoman Land Code 1858. Persons who cultivated land classified as mewat could obtain ownership of it if they registered the land within 2 months of the entry into force of the regulation (Rangwala 2004; Nasasra 2012, 95).

${ }^{8}$ The Provision law of 1958 also repealed some of the British regulations regarding Ottoman land classifications. 
construction on land classified as agricultural) and claims that there are too few inhabitants in them. Those laws are, at the same time, differently interpreted regarding Jewish settlements in the region (Rangwala 2004; Yiftachel 2009), showing that certain juristic categories are used only as a tool of Judaization.

As the Bedouins villages are not recognized, they are not subject to the administrative authority, so their inhabitants cannot apply for a possible building permit or change the classification of their land. Moreover, according to the Planning and Building Act (1965), even if private ownership of terrain is uncontested (Bedouins have a deed of ownership) or can be proved, any real estate in parcels zoned as agricultural is still unlawful. Art. 157a of the Planning and Building Act of 1965 also prohibits state-owned companies from providing municipal services or connecting illegal buildings to utilities (Rangwala 2004). Unrecognized localities are therefore deprived of access to roads, fresh water, electricity, medical care, education and other services (Abu-Saad 2008; Swirski and Hasson 2006; Yiftachel 2009). In case of those localities, codes of oppositions between the "primitive and wild" and "civilized and urban" are again used. Those places, due to lack of services, are characterized by higher levels of poverty, crime, and infant and child mortality (Yiftachel 2009). In political rhetoric, Bedouins living in unrecognized locations are named as criminals, savage tenants and intruders (Cook 2008, 36-37). Fostering fear of "illegal" neighbours by using stereotyped categories leads to an exacerbation of the ethnic-class conflict and deepens the social exclusion of the Bedouins. For decades now, Israel has been trying to evict Bedouins by a campaign of house demolitions (Fields 2017, 276), however to no avail.

In result, unrecognized villages are certain suspended beings - although they exist materially and can be visited (or demolished), in official administrative regulations and maps they do not exist. Their demolition because they do not have the administrative status of official settlements shows the advantage of abstract administrative regulations, expressing the imaginative geographies of those in power - over the facts in space. As the Bedouin settlements do not fit the desired imaginative geographies, not only are they spatially excluded, but the government has tried to erase them both physically and symbolically. On the latter level, the recreation of Negev takes the form of wiping out historical memory about localities. Around Beer Sheva, the names of around 45 Bedouin towns are never officially used in legal documents or maps, making these towns and their inhabitants, in a symbolic sense, "invisible" or even "non-existent." Arabic names of regions, topographic and historical points were also replaced with Hebrew names, to hide traces of Arab past (Benvenisti 2001). In effect, symbolic nonexistence of "unrecognized villages" in documents and maps becomes the basis of performative actions to physically erase them, to reshape reality on a basis of imaginations of space. 


\section{CONCLUSIONS}

As a result of the resettlement strategies and regulations introduced by Israel, currently, $93 \%$ of the grounds in the country are owned publicly - by the state, JNF, and the state Development Agency (Israel Land Authority n.d.). Of the 7\% of nonstate owned land, only 3\% is in private Palestinian hands, which are also subject to Israeli administration and planning, and thus, in principle, cannot be used by the owners at will (Cook 2013, 37-38). Although most of the region was taken over by the state based on the aforementioned regulations, many of the Bedouins contest this form of legalistic dispossession and continue living in their villages, fighting to recognize their rights. As a result, instead of Israel taking over the imagined "empty land without people," where Judaization can be put into practice without hindrance, the government faces a situation in which it may succeed in taking over the territories (although the legality of transferring ownership rights to the state is widely questioned by Israeli, Palestinian and foreign lawyers, politicians and activists), but it is still inhabited by native people, who make justified claims to their fundamental rights. Nevertheless, new ideas of mass resettlements of Palestinians, also to the Negev, are still being proposed. The latest "imaginative geographies" of this land (this time representations of US ideas) described at length is the 2020 peace plan, better known as the "Deal of the Century," prepared by US administration of President Donald Trump (Peace to Prosperity 2020).

The analysis here shows that such visions, even if seemingly idealistic or far from on-the-ground reality, can be reproduced in space. In Israel such processes took place, largely through introducing laws and juristic categories which drew from collective imaginations of the settler state. Law has three specific aspects here: it is an expression of imagined geographies; it translates those visions into technical terms; and lastly, the implementation of its provisions becomes the main instrument of producing those representations in reality. In this case, it also becomes visible that the Judaization of the space through law largely took place at a symbolic level, by creating new terms and legal facts (such as "abandoned lands," "absentee property" "unrecognised villages" etc.). The Bedouins of the Negev were largely marginalized through such symbolic actions, in the end becoming excluded and invisible in the official discourses. Thus, in line with strategies of the settler state, and in the process of Judaization of landscapes, the "imaginative geographies" of the Negev were produced in reality.

\section{BIBLIOGRAPHY}

Absentees' Property Law, 5710-1950. UNISPAL. Accessed January 5, 2020. https://unispal.un.org/ DPA/DPR/unispal.nsf/0/E0B719E95E3B494885256F9A005AB90A

Abu-Saad, Ismael. 2008. "Spatial Transformation and Indigenous Resistance: The Urbanization of the Palestinian Bedouin in Southern Israel.” American Behavioral Scientist 51(12): 1713, 1754. 
Adalah. n.d. "New Discriminatory Laws and Bills in Israel, 29 November 2010." Adalah - The Legal Center for Arab Minority Rights in Israel. Accessed January 12, 2020. http://www. europarl.europa.eu/meetdocs/2009_2014/documents/dplc/dv/adallah_discriminatory_isra/ adallah_discriminatory_israel.pdf

Alon, Tal. 2006. „National Report of Israel Years 2003-2005 to the United Nations Convention to Combat Desertification (UNCCD)." Accessed January 10, 2020. http://www.unccd-prais. com/Uploads/GetReportPdf/72fa62fe-322a-4573-81c4-a0fa014a4b35

Amara, Ahmad and Oren Yiftachel. 2014. Confrontation in the Negev: Study Commissioned by the Rosa-Luxemburg-Stiftung. Berlin: Rosalux.

Amara, Ahmad and Zinaida Miller. 2012. "Unsettling Settlements: Law, Land, and Planning in the Naqab." In Indigenous (In) Justice: Human Rights Law and Bedouin Arabs in the Naqab/ Negev. 68-125. Edited by Ahmad Amara, Ismael Abu-Saad and Oren Yiftachel. Cambridge: Harvard Law School.

Basic Law: Israel Lands. Knesset. Accessed January 5, 2020. https://www.knesset.gov.il/laws/ special/eng/basic13_eng.htm

Benvenisti, Meron. 2000. Sacred Landscape: The Buried History of the Holy Land Since 1948. Oakland: University of California Press.

Boteach, Elana. 2006. The Indigenous Bedouins of the Naqab-Negev Desert in Israel: Submitted to the UN Permanent Forum on Indigenous Issues. Beer Sheva: Negev Coexistence Forum for Civil Equality.

Comaroff, John L. 2001. "Colonialism, Culture, and the Law: A Foreword." Law \& Social Inquiry 26(2): 305-314.

Cook, Jonathan. 2013. Disappearing Palestine: Israel's Experiments in Human Despair. London: Zed Books Ltd.

Dajani, Souad R. 2005. Ruling Palestine: A History of the Legally Sanctioned Jewish-Israeli Seizure of Land and Housing in Palestine. Centre on Housing Rights and Evictions, COHRE.

Delaney, David. 2014. "At Work in the Nomosphere: The Spatiolegal Production of Emotions at Work.” In The Expanding Spaces of Law: A Timely Legal Geography. 239-262. Edited by Irus Braverman, Nicholas Blomley, David Delaney and Alexandre (Sandy) Kedar. Stanford: Stanford Law Books.

Eisenman, Robert H. 1978. Islamic Law in Palestine and Israel: A History of the Survival of Tanzimat and Sharī'a in the British Mandate and the Jewish State, vol. 26. Leiden: Brill.

Fields, Gary. 2017. Enclosure: Palestinian Landscapes in a Historical Mirror. Berkeley: University of California Press.

Forman, Geremy and Alexandre Kedar. 2003. "Colonialism, Colonization and Land Law in Mandate Palestine: The Zor al-Zarqa and Barrat Qisarya Land Disputes in Historical Perspective." Theoretical Inquiries in Law 4(2): 491-539.

Forman, Geremy and Alexandre Kedar. 2004. "From Arab land to 'Israel Lands': The Legal Dispossession of the Palestinians Displaced by Israel in the Wake of 1948." Environment and Planning D: Society and Space 22(6): 809-830.

George, Alan. 1979. “'Making the Desert Bloom': A Myth Examined.” Journal of Palestine Studies 8(2): $88-100$.

Gregory, Derek. 1995. "Imaginative Geographies." Progress in Human Geography 19(4): 447-485.

Gregory, Derek. 2004. "Palestine and the War on Terror." Comparative Studies of South Asia, Africa and the Middle East 24(1): 183-195.

The Inter-Agency Task Force. n.d. Negev Bedouin. Accessed September 2, 2019. http://www. iataskforce.org/issues/view/2

Israel Land Authority. n.d. “About Israel Land Authority.” Accessed January 16, 2020. http://land. gov.il/en/Pages/AboutUs.aspx 
Israel Lands Administration Law 5720-1960, Laws of the State of Israel: Authorized Translation from the Hebrew, vol. 14. Accessed September 2, 2019. https://www.adalah.org/uploads/ oldfiles/Public/files/Discriminatory-Laws-Database/English/08-Israel-Land-AdministrationLaw-1960.pdf

Israeli Government Covenant. n.d. KKL-JNF - Israeli Government Covenant. Accessed September 3, 2017. http://www.kkl-jnf.org/about-kkl-jnf/kkl-jnf-id/kkl-jnf-israeli-government-covenant/

Israeli Ministry of Justice. n.d. "Expropriations Objections Committee.” Accessed January 16, 2020. http://www.justice.gov.il/En/Units/ExpropriationsObjectionsCommittee/Pages/default.aspx

Jewish National Fund. n.d. "Our History." Accessed January 17, 2020. https://www.jnf.org/ourhistory

Kedar, Alexandre (Sandy). 2003. „On the Legal Geography of Ethnocratic Settler States: Notes Towards a Research Agenda." Current Legal Issues 5: 401-441.

Kimmerling, Baruch. 1983. Zionism and Territory: The Socio-Territorial Dimensions of Zionist Politics. Berkeley: Institute of International Studies, University of California.

Land Acquisition (Validation of Acts and Compensation) Law, 5713-1953. Jewish Voice for Peace. Accessed January 5, 2020. https://jewishvoiceforpeace.org/wp-content/uploads/2016/06/ Israeli-Land-Acquisition-Law-1953.pdf

Lefebvre, Henri. 1991. The Production of Space. Translated by Donald Nicholson-Smith. Oxford: Blackwell.

Nasasra, Mansour. 2012. "The Ongoing Judaisation of the Naqab and the Struggle for Recognising the Indigenous Rights of the Arab Bedouin People.” Settler Colonial Studies 2(1): 81-107.

Pappé, Ilan. 2006. The Ethnic Cleansing of Palestine. London: Oneworld Publications.

"Peace to Prosperity. A Vision to Improve the Lives of the Palestinian and Israeli People." 2020.

The Whitehouse. US State. Accessed January 29, 2020. https://www.whitehouse.gov/media/ peace-prosperity-full-plan/

Rangwala, Tawfiq S. 2004. "Inadequate Housing, Israel, and the Bedouin of the Negev." Osgoode Hall Law Journal 42: 415-472.

Said, Edward W. 1978. Orientalism. New York: Pantheon Books.

Shamir, Ronen. 1996. "Suspended in Space: Bedouins Under the Law of Israel." Law and Society Review. 30(2): 231-257.

Shehadeh, Raja. 1993. The Law of the Land: Settlements and Land Issues Under Israeli Military Occupation. Jerusalem: Passia.

Swirski, Shlomo and Yael Hasson. 2006. Invisible Citizens. Israel Government Policy Toward the Negev Bedouin. Beer Sheva: Adva Center.

Yiftachel, Oren. 1999. “"Ethnocracy': The Politics of Judaizing Israel/Palestine.” Constellations 6(3): 364-390.

Yiftachel, Oren. 2004. 'Understanding 'Ethnocratic' Regimes: The Politics of Seizing Contested Territories." Political Geography 23(6): 647-676.

Yiftachel, Oren. 2006. Ethnocracy: Land and Identity Politics in Israel/Palestine. Philadelphia: University of Pennsylvania Press.

Yiftachel, Oren. 2009. “Creeping Apartheid in Israel-Palestine.” Middle East Report 253: 7-15. 